\title{
SCHEMA ACTIVATION STRATEGY IN READING COMPREHENSION TO IMPROVE STUDENT'S INTEREST
}

\author{
Rizky Hidayatullah, Andika Ari Saputra, Dian Risky Amalia, \\ dan Umar Alfaruq A. Hasyim \\ Fakultas Tarbiyah, Institut Agama Islam Ma'arif NU Metro \\ e-mail: rizky.hidayatullah17@gmail.com,ari.andika75@yahoo.com
}

\begin{abstract}
This research is aimed to improve the reading comprehension through schema activation strategy. Classroom Action Research (CAR) was conducted in two cycles and each cycle consisted of four phases. They were planning, acting, observing, and reflecting. The subjects of the study were 34 students of Class VIII A of SMP Muhammadiyah 1 Godean. There were two forms of data in this study. The qualitative data were collected through observation and interview. The data were presented in the form of field notes and interview transcripts. Then, the quantitative data were collected through Pre-test, Posttest I, and Posttest II. In reference to the application of the two cycles, the results of the research revealed that use of schema activation strategy successfully improved the students' reading comprehension. The students" interest and attention in the process of teaching and learning English, especially reading improved. They were also able to explore many words related to the topic of the lesson. In relation to their comprehension of English texts, the students were able to identify main ideas and supporting details of paragraphs correctly.
\end{abstract}

Keywords: reading comprehension, Schema Activation Strategy, student interest

\section{STRATEGI SKEMA PADA MATERI READING COMPREHENSION UNTUK MENINGKATKAN KETERTARIKAN SISWA}

\begin{abstract}
Abstrak
Penelitian ini bertujuan untuk meningkatkan pemahaman reading comprehension melalui penggunaan Schema Activation Strategy. Dalam melakukan penelitian ini, Peneliti menggunakan Penelitian Tindakan Kelas (PTK) sebagai metode penelitian. Penelitian dilakukan dalam dua siklus dan masing-masing siklus terdiri dari empat fase. Yaitu fase persiapan, aksi, observasi dan refleksi. Subjek penelitian adalah 34 siswa dari kelas VIII A SMP Muhammadiyah 1 Godean. Ada dua macam data yang dihimpun pada penelitian ini. Data kualitatif dikumpulkan melalui observasi dan wawancara. Kemudian data dipresentasikan dalam bentuk catatan dan transkip wawancara. Sedangkan, data kuantitatif dikumpulkan melalui Pre-Test, Post-test I, dan Post-test II. Hasil yang didapatkan setelah menerapkan dua siklus, yaitu penggunaan Schema Activation Strategy berjalan sukses meningkatkan pemahaman siswa pada bab Reading. Minat siswa dan perhatian dalam proses pengajaran dan pembelajaran bahasa Inggris, khususnya peningkatan dalam pemahaman Reading. Para siswa mampu mengeksplorasi banyak kata terkait topik pelajaran. Para siswa juga mampu memahami teks Bahasa Inggris, siswa juga mampu untuk mengindentifikasi ide pokok dan juga detail paragaraf secara benar.
\end{abstract}

Kata Kunci: Strategi Schema Activation, pemahaman reading, minat siswa

\section{INTRODUCTION}

Mastering reading is very important for students to be able to master English's skills. For example, a student who wants to be a good writer, they have to be a good reader. Unfortunately, common readers, especially young learners, do not have a good reading comprehension in 
understanding English passages well and effectively. There are several problems that appear in the field of education. First, the students usually found difficulties in comprehending the text if they did not know a lot of the words in the text. Making prediction activity was also successful to build connection between the students prior knowledge and the new material. Students were able to make some predictions about the text by looking at the detail of the pictures and the title of the text. Those activities made the students comprehend the text more easily.

According to Moreillon (2007), there are Schema Activation Strategy. A schema is a mental structure in which people store all the information they know about people, places, objects, or activities. If people have no schema for a particular topic, they begin that encounter with an immediate loss of comprehension. This metaphor helps educators think in terms of the necessity of familiarity and comfort with a topic if the reader is to be successful at making meaning. By assessing students' schemas and activating or building background knowledge, they offer students critical support for comprehension. In addition, Brown (2001) also states that content schemata includes what we know about people, the world, culture, and the universe, while formal schemata consists of our knowledge about discourse structure.

Zhao \& Zhu (2012:111) said that comprehension is termed as an interactive process which works between the text and reader's background knowledge. Therefore, it always happens that readers contribute more information than the print on page. Readers understand what they read since during reading they tend to take the stimulus beyond its graphic representation and assign its membership to an appropriate group of concepts which are already stored in their memories. The reading process, therefore, involves comprehend it. Nevertheless, they must be able to relate new things to what they already know if they are to comprehend texts. In other

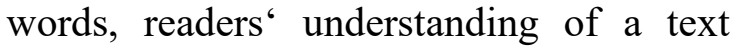

depends on how much related schemata which the readers possess while reading.

Anderson's (1994:469) states that research stresses that more than one interpretation of text is possible; the schema that is activated is based on the culture of the reader. Relation between schema theory and reading comprehension cannot be denied that schema or readers 'background knowledge gives a big contribution for the success of comprehending a text. Relevant research according to Tanjung, Astuti, \& Arisandi (2019: 377), interest can increase student participation in learning, and make students more active and responsive in understanding a lesson. The importance of activating readers' background knowledge, teachers should be able to create and conduct some strategies which are able to recall and relate students' background knowledge with the text given.

Moreillon (2007) suggests that readers make three types of connection in building their schema. They are text-to-self, text-to-text, and text-to-world. Text-to-self connections require that educators know the children in their care and be familiar with students' home lives and local communities. When modelling text-to-self connections, educators can use think-aloud questioning to share their thinking processes. Posing and answering questions can be an effective vehicle for making comprehension through background knowledge accessible to students. When educators make effective connections between students' home and school lives, and as students build their school-based background knowledge, learners can be guided to make connections between texts.

Snow (2002: 11) defines reading comprehension as the process of simultaneously extracting and constructing meaning through interaction and involvement with written language. Such three dimensions as the reader, the text and the activity are entailed from the definition. The identities and capacities of readers, the texts that are available and valued, and the activities in which readers are engaged with those texts are all influenced by, and in 
some cases, determined by, the sociocultural context. The sociocultural context mediates students' experiences, just as students' experiences influence the context (Snow, 2002).

In relation to the above theories, Lenz (2005) puts forward that reading comprehension is the process of construting meanings from the text. It means that the reading comprehension process involves the student's ability to make relationship between his/her background knowledge and their purpose of reading with the meanings of the text. Koda (Grabe, 2009) highlights that comprehension occurs when the student extracts and integrates various information from a text, and combines it with what is already known. Furthermore, Carrel and Eisterhold (1983) claim that comprehending a text is an interactive process between the student's background knowledge and the text. Efficient comprehension requires the ability to relate the textual material to one's own knowledge.

In general, the processes of comprehension involve top-down, bottomup, and interactive process. Carrell \& Eisterhold (1983: 557) notes that bottom-up processing is evoked by the incoming data; the features of the data enter the system through the best fitting, bottom-level schemata. Schemata are hierarchically organized, from most general at the top to the most specific at the bottom. In bottomup processing, readers have to recognize linguistic signals such as letters, morphemes, syllables, words, phrases, grammatical cues, discourse markers and impose them with their linguistic dataprocessing mechanisms (Brown, 2001). The readers identify the components of a text from smaller components up to the bigger one.

Top-down is the process used by the readers to understand a text through their knowledge. Goodman in Brown (2001: 299) notes that in top-down model, readers were required to make use their background knowledge to make prediction and inference in order to understand the reading texts. Readers start with the largest elements and work down towards smaller elements to build comprehension of what is being read (Anderson in Nunan, 2003: 71). In this process, reading begins with the reader background knowledge.

Another process is the combination of bottom-up and top-down. It is usually called as an interactive processing. Proccesing sees reading as a process of interaction between top-down and bottom up skills, supporting a combination of language development, decoding and strategy development. It combines the ability when reading the text itself and utilizes the background knowledge in mind to understand what a text is about.

The use of comprehension strategies in the teaching of reading is important. It influences the students ' reading comprehension. In relation to the use of reading comprehension strategies Zimmerman and Hutchins cited in Moreillon (2007) propose seven strategies. Some of them are as follows.

Activating or Building Background Knowledge; Activating background knowledge refers to students recalling what students know about the topic of a text before reading and during reading for learning the content as fully as possible and linking the new content to prior understanding. When the reader can connect what he/she is reading to something already known, background knowledge is being utilized to make sense of the new information.

Second is Using Sensory Images; Sensory experiences are a significant aspect of student's background knowledge. When people think about their sensory experiences, they are creating representations of those experiences in their memories (Marzano in Moreillon, 2007). In this strategy, the use of senses (sight, hearing, touch, taste and smell) in understanding texts plays an important role. Inviting students to close their eyes and imagine the text as it is read aloud, and then asking them to share the pictures in their 
heads, is the basic technique used to teach visualization.

Then, Questioning; Questioning refers to students asking or writing selfinitiated questions about the content of a text, before and during reading, to help them understand the text and the topic. Students' reading processes change dramatically when they pose questions about the topic of a book or text before reading. Their questioning serves several roles in the comprehension process. If they are students ' personal questions, they come from the students' knowledge. They flow out of personal experiences and represent those experiences as the students encounter new ones.

In teaching English, a teacher as the center and facilitator to the students in the classroom needs to prepare some teaching strategies and principles to teach the students so that they can understand well what the teacher teaches in the classroom. According to Harmer (2001), there are six teaching principles that may be appropriate in teaching reading that is summarized below. First, reading is not a passive skill. Reading is an incredibly active occupation. To do it successfully, readers have to understand what the words mean, see pictures the words are painting, and understand the arguments. If readers do not do those things, then they only just scratch the surface of the text and quickly forget it.

Second, students need to be engaged with what they are reading. Students who are not engaged with the reading text, not actively interested with what they are doing, are less likely to benefit from it. When they are really fired up by the topic or the task, they get much more from what is in front of them. Students should be encouraged to respond to the content of a reading text, not just to the language.

It is important to study reading texts for the way they use language, the number of paragraphs they contain and how many times they use relative clauses. However, the meaning, the message of the text, is important and teachers must give students a chance to respond to that message in some ways. It is especially important that students should be allowed to express their feelings about the topic.

And third, Types of Classroom Performance in Reading. According to Brown (2001), variety of reading performance in the language classroom is derived more from the variety of texts than from the variety of overt types of performance. Those types of classroom reading performance are explained as follows.

Oral and silent reading. Occasionally, a teacher has a reason to ask a student to read orally. At the beginning and intermediate levels, oral reading can serve as an evaluative check on bottom-up processing skills, double as a pronunciation check, andserve to add some extra student participation if the teacher wants to highlight a short segment of a reading passage (Brown, 2001).

Intensive and extensive reading, according to Brown (2001), silent reading may be subcategorized into intensive and extensive reading. Intensive reading is usually a classroom-oriented activity in which students focus on the linguistic or semantic details of a passage. Intensive reading calls students' attention to grammatical forms, discourse markers, and other surface structure details for understanding literal meaning, implications, rhetorical relationship, and the like. Intensive reading may also be a totally content-related reading initiated because of subject-matter difficulty.

Extensive reading is carried out to achieve a general understanding of a longer text. Most extensive reading is performed outside of class time. Therefore, pleasure reading is often extensive. By stimulating reading for enjoyment or reading where all concepts, names, dates, and other details need not be retained, students gain an appreciation for the effective and cognitive window of reading (Brown, 2001).

When having a reading activity in the classroom, teachers should not ask students to read certain text on certain page without any introduction or hints on anything 
special to do while reading. According to Brown (2001), there is three-part framework in teaching reading. They are Before reading. In this part, teachers should spend some time introducing a topic, encouraging skimming, scanning, predicting, and activating schemata. Students can bring the best of their knowledge and skills to a text when they have been given a chance to ease intoll the passage.

While reading. In this part, teachers should give students a sense of purpose from reading rather than just reading because they are ordered to do that. After reading. The focus of this part is a form of activity appropriate for post-reading. The activity can be in the form of studying vocabulary, identifying the author's purpose, discussing the author's line of reasoning, examining grammatical structures, or steering students toward a follow up writing exercise.

\section{METHODS}

Burn (1999) states that action research is the application of fact finding to practical problem solving in a social situation with a view to improve the quality of action within it, involving the collaboration and cooperation of researchers, practitioners and laymen.

This action research uses the model developed by Kemmis and McTaggart. According to the model, the implementation of the action research includes four steps. They are as follows, identifying problems and planning the action, implementing the action and observing or monitoring the action, reflecting the result of the observation, and, revising the plan for the following step (Burns, 1999).

The subject of the research was the eighth grade students of SMP Muhammadiyah 1 Godean. The eighth grades are divided into five classes. They are class VIII A up to VIII E. In this research, the writer chose VIII A. This class consists of 30 students.

The researcher will use the action research procedures suggested by Burns (1999). The procedures consisted of the following steps: preliminary activity, planning, action and observation, reflection.

The first technique of collecting data using qualitative method consists of observation, fieldnotes and interview. The researcher did an observation dealing with the real situation of the teaching and learning process. Notes or field notes are descriptions and accounts of events in the research context which are written in relatively factual and objective style (Burns, 1999). The researcher took notes in each observation done. The researcher took notes to all activities during the lesson and also noted about the students' reaction and response to the learning.

The teacher conducted interviews from pre-research, in the process of action and at the end of the research. The researcher made interviews with the teacher and the students. In the pre-research, the researcher made interviews in order to know problems that both the teacher and the students faced especially in reading a lesson. The interview were given in the process of the action and at the end of the research was aimed to know how far the action influences the students' reading comprehension.

Second, the technique of collecting the data using quantitative method is a test. In this research, the researcher used the objective test type for both pre-test and post-test. The result of the test was analyzed to know the students ability in reading comprehension. The result could indicate whether the use of schema activation strategy was effective or not.

\section{RESULT AND DISCUSSION Result}

Preliminary activity

The first step in conducting this research was diagnosing the problems in the reading comprehension and learning process. A field survey would be carried out to know the real condition of the class that would be used to apply the researcher's classroom action research. The forms of the survey were interview, class observation 
and pre-test. The interview was done with an English teacher and some students from their classes. The questions were about the general condition about teaching reading comprehension, the teachers' activities and strategy, and the students' problem in reading class.

\section{Pre-Test}

The test was conducted on July 20, 2016 then the result of the data showed that twenty five students or $73.52 \%$ belonged to very poor category because they got score less than 50. There were six students or $17.64 \%$ who belonged to poor category since they got score between $50-59$. Two students or $5.44 \%$ who got score between 60- 69 and they belonged to average category. There was a student or $2.94 \%$ who belonged to good category because he got score between $70-85$ and none of the students gained more than 85 . The mean was 45.21 The highest score obtained was 76 , and the lowest score obtained was 28 . It could be said that only one of thirty four students or $2.94 \%$ passed based on KKM, while others failed.

\section{Post-Test I}

Post-test II was carried out on Thursday, July 28,2016 . The result showed that eleven students or $32.35 \%$ got score between 60- 75 and belonged to average category. There were nine teen students or $55.88 \%$ belonged to good category because they got score between $76-85$. There were four students or $11.76 \%$ achieved more than 85 the mean was 76.58, It was higher than the mean in the pre-test. The highest score obtained was 88, and the lowest score obtained was 60 . There was improvement of the students' reading comprehension after schema activation strategy was applied. The majority of the students increased their score but the target had not been achieved yet because only twenty four of thirty four students or $67.64 \%$ who had passed KKM or Minimum Competence Criteria or KKM while the other student failed.
Post-Test II

The post-test was conducted on Thursday, August 4, 2016. The result showed that There was one student or 2.94 $\%$ who belonged to very poor category because his score was between 0-49 There were three students or $8.82 \%$ who belonged to average category because their scores were between $60-75$. There were fourteen students or $41.17 \%$ who belonged to average category because their scores were between $76-85$. There were sixteen students or $47.05 \%$ who belonged to very good category because their scores were between $86-100$. The mean was $83.17 \%$. It was higher than the mean in post-test 1 . The highest score obtained was 96, and the lowest score obtained was 44 . There was some improvement in the students' reading comprehension after schema activation strategy was applied. The majority of the students passed the passing score based on KKM or Minimum Competence Criteria. Interview

A conversation had been discussed with teacher who taught eighth grade students. The result of interview with the teacher were as follows: student enjoyed in learning reading comprehension, and the teacher got easy in reading teaching learning process.

An interview had been done with some students of eighth grade about reading comprehension. the students had been found out in reading comprehension were as follows: the students felt enjoy with the strategy, the students were not bored of the reading class, the students found it easy to comprehend reading text, the students found it easy to comprehend the meaning of question in English.

\section{Discussion}

Based on the data analyzed in this research, the use of Schema Activation Strategy was effective to improve the students' reading comprehension. The four steps, i.e. building the students ' interest and attention, accessing prior knowledge and exploring key words, building connection between the students' prior knowledge and 
the new material, and comprehending the new material were effective to activate the students' schemata. As the result, those steps enabled the students to understand the text more easily.

The uses of pictures and of Questioning and Answering session were successful to build the students' interest and attention. The activity of Questioning and Answering the detail of the pictures was effective to assess the students ${ }^{\text {' }}$ prior knowledge. Making prediction activity was also successful to build connection between the students' prior knowledge and the new material. Students were able to make some predictions about the text by looking at the detail of the pictures and the title of the text. Those activities made the students comprehend the text more easily.

Relevant research according to Zhao \& Zhu (2012: 111) comprehension is termed as an interactive process which works between the text and reader's background knowledge. Therefore, it always happens that readers contribute more information than the print on page. Readers understand what they read since during reading they tend to take the stimulus beyond its graphic representation and assign its membership to an appropriate group of concepts which are already stored in their memories. The reading process, therefore, involves comprehend it. Nevertheless, they must be able to relate new things to what they already know if they are to comprehend texts. In other words, readers' ${ }^{6}$ understanding of a text depends on how much related schemata which the readers possess while reading.

\section{CONCLUSION}

Schema activation strategy was effective to improve student's interest in reading comprehension base on the result of research, improvement from Pre-test, Cycle 1, Cycle 2 and also Post-test, beside the strategy is interesting to the students because the strategy can use some media, e.g : picture, sound and also video base on teacher's strategies and also the subject of the teaching.

\section{REFERENCE}

Anderson, R. C. (1994). Role of the Reader's Schema in Comprehension, Learning, and Memory. Theoretical models and processes of reading. Newark, Del.

Brown, H. (2001). Teaching by Principles:

An Interactive Approach to Language Pedagogy (2nd Ed). San Francisco: Longman.

Burns, Anne. (1999). Collaborative Action Research for English Language Teachers. New York: Cambridge University Press.

Carrell, P. L., \& Eisterhold, J. C. (1983). Schema theory and ESL reading pedagogy. TESOL quarterly, 17(4), 553-573. doi: $10.2307 / 3586613$

Grabe, William. (2009). Reading in a Second Langauge: Moving from Theory to Practice. New York: Cambridge University Press.

Guthrie, John, T., Allan Wigfield, Kathleen C. Perencevich. (2004). Motivating Reading Comprehension. New Jersey: Lawrence Erlbaum Associates, Inc.

Harmer, J. (2001). The Practice of Language Teaching (3rd Ed). London: Longman Group Ltd.

Lenz, K. (2005). An Introduction to Reading Comprehension. Available website:http//www.specialconnecti ons.ku.edu.//

Moreillon, Judy. (2007). Collaborative Strategies for Teaching Reading Comprehension. Chicago: American Library Association.

Nunan, D. (Ed). (2003). Practical English Language Teaching. New York: McGraw-Hill.

Snow, C E. (2002). Reading for Understanding: toward a reasearch and development program in reading comprehension. Arlington: RAND Education.

Tanjung, Y., Astuti, B., \& Arisandi, A. (2019). Influence of Group Guidance with Discussion 
Techniques on Local Learning Interest. KnE Social Sciences, 377388. doi: 10.18502/kss.v3i17.4662
Zhao, X., \& Zhu, L. (2012). Schema Theory and College English Reading Teaching. English Language Teaching, 5(11), 111-117. Retrieved from https://eric.ed.gov/ ?id=EJ1080109 